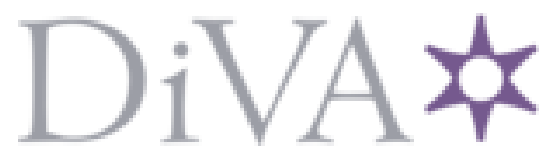

http://www.diva-portal.org

This is the published version of a chapter published in Early Medieval Stone Monuments: Materiality, Biography, Landscape.

Citation for the original published chapter:

Back Danielsson, I-M. (2015)

Walking Down Memory Lane: Rune-Stones as Mnemonic Agents in the Landscapes of Late Viking-Age Scandinavia.

In: Howard Williams, Joanne Kirton and Meggen Gondek (ed.), Early Medieval Stone Monuments: Materiality, Biography, Landscape (pp. 62-86). Woodbridge: Boydell \& Brewer Boydell Studies in Medieval Art and Architecture

N.B. When citing this work, cite the original published chapter.

Permanent link to this version:

http://urn.kb.se/resolve?urn=urn:nbn:se:uu:diva-280475 
EARLY MEDIEVAL STONE MONUMENTS 
BOYDELL STUDIES IN MEDIEVAL ART AND ARCHITECTURE

ISSN 2045-4902

Series Editors

Dr Julian Luxford

Dr Asa Simon Mittman

This series aims to provide a forum for debate on the art and architecture of the Middle Ages. It will cover all media, from manuscript illuminations to maps, tapestries, carvings, wall-paintings and stained glass, and all periods and regions, including Byzantine art. Both traditional and more theoretical approaches to the subject are welcome.

Proposals or queries should be sent in the first instance to the editors or to the publisher, at the addresses given below.

Dr Julian Luxford, School of Art History, University of St Andrews, 79 North Street, St Andrews, Fife, KY16 9AL, UK

Dr Asa Simon Mittman, Department of Art and Art History, California State University at Chico, Chico, CA 95929-0820, USA

Boydell \& Brewer, PO Box 9, Woodbridge, Suffolk, IP12 3DF , UK

\section{ALREADY PUBLISHED}

The Art of Anglo-Saxon England

Catherine E. Karkov

English Medieval Misericords: The Margins of Meaning

Paul Hardwick

English Medieval Shrines

John Crook

Thresholds of Medieval Visual Culture: Liminal Spaces

Edited by Elina Gertsman and Jill Stevenson

The Marvellous and the Monstrous in the Sculpture of Twelfth-Century Europe Kirk Ambrose 


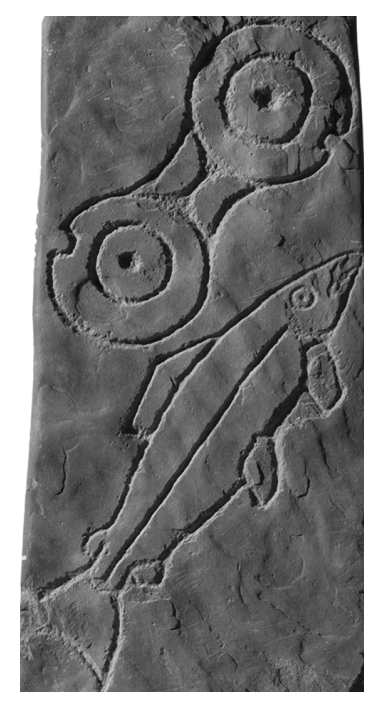

\section{EARLY MEDIEVAL} STONE MONUMENTS: MATERIALITY, BIOGRAPHY, LANDSCAPE
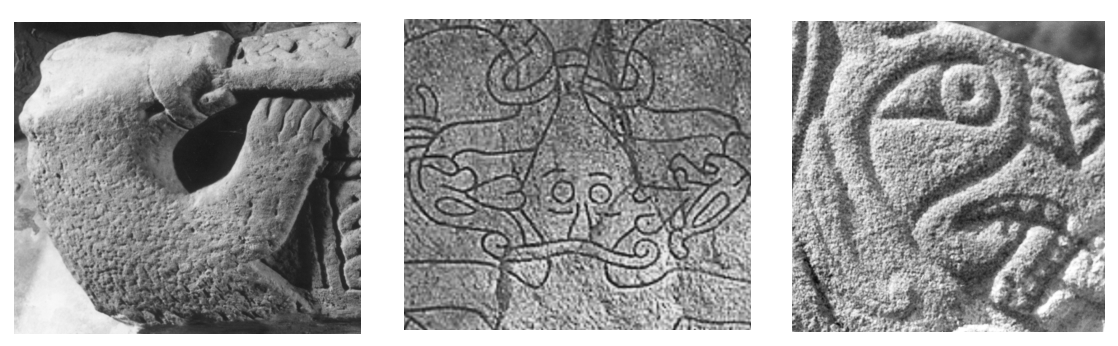

Edited by

Howard Williams, Joanne Kirton and Meggen Gondek 
All Rights Reserved. Except as permitted under current legislation no part of this work may be photocopied, stored in a retrieval system, published, performed in public, adapted, broadcast, transmitted, recorded or reproduced in any form or by any means, without the prior permission of the copyright owner

First published 2015

The Boydell Press, Woodbridge

ISBN 978-1-78327-074-3

The Boydell Press is an imprint of Boydell \& Brewer Ltd PO Box 9, Woodbridge, Suffolk IP12 3DF, UK and of Boydell \& Brewer Inc. 668 Mt Hope Avenue, Rochester, NY 14620-2731, USA website: www.boydellandbrewer.com

The publisher has no responsibility for the continued existence or accuracy of URLs for external or third-party internet websites referred to in this book, and does not guarantee that any content on such websites is, or will remain, accurate or appropriate.

This publication is printed on acid-free paper

A CIP catalogue record for this book is available from the British Library 


\section{CONTENTS}

List of Illustrations ix

List of Tables xiii

Acknowledgements xiv

1 Introduction: Stones in Substance, Space and Time 1 Howard Williams, Joanne Kirton and Meggen Gondek

2 Locating the Cleulow Cross: Materiality, Place and Landscape $\quad 35$ Joanne Kirton

3 Walking Down Memory Lane: Rune-Stones as Mnemonic Agents in the Landscapes of Late Viking-Age Scandinavia 62 Ing-Marie Back Danielsson

4 Building Blocks: Structural Contexts and Carved Stones in Early Medieval Northern Britain $\quad 87$ Meggen Gondek

5 Memory, Belief and Identity: Remembering the Dead on Iniscealtra, Co. Clare 114 Clíodhna O'Leary

6 The Biographies and Audiences of Late Viking-Age and Medieval Stone Crosses and Cross-Decorated Stones in Western Norway Iris Crouwers

7 Lifeways in Stone: Memories and Matter-Reality in Early Medieval Sculpture from Scotland Mark A. Hall 
8 A Stone in Time: Saving Lost Medieval Memories of Irish Stone Monuments

216

Jenifer Ní Ghrádaigh

9 Hogbacks: the Materiality of Solid Spaces

241 Howard Williams

List of Contributors

Index

271 


\section{ILLUSTRATIONS}

1.1 Tenth-century cross at Maen Achwyfan, Flintshire. Photo (c) Howard Williams 2008

1.2 The east side (C) of Maen Achwyfan, Flintshire. Photo (C) Howard Williams 2010

1.3 Modern cross at Heavenfield, Northumberland. Photo (c) Howard Williams 2006

1.4 Detail of the north cross from Sandbach, Cheshire. Photo (c) Howard Williams 2006

1.5 The Pillar of Eliseg in its modern landscape context. Photo (C) Howard Williams 2011

1.6 The Pillar of Eliseg looking north during excavations in 2011. Photo (c) Howard Williams 2011

2.1 Round-shaft monuments in Prestbury. Drawn by Joanne Kirton. Base map Crown Copyright/database right 2012. An Ordnance Survey/Edina supplied service

2.2 Cleulow Cross, Wincle. Photo (c) Joanne Kirton

2.3 The mound as viewed from the east. Photo (c) Joanne Kirton

2.4 Map of known monuments, earthworks and find spots around the Cleulow Cross, Wincle. Drawn by Joanne Kirton: Base map Crown Copyright/database right 2012. An Ordnance Survey/Edina supplied service

2.5 Bullstones. Photo (C) Joanne Kirton

2.6 Wincle viewshed. Drawn by Joanne Kirton. Base map Crown Copyright/database right 2012. An Ordnance Survey/Edina supplied service

2.7 Viewshed from the Bowstones, Disley Lyme Handley. Drawn by Joanne Kirton. Base map Crown Copyright/database right 2012. An Ordnance Survey/Edina supplied service

2.8 Road map. Drawn by Joanne Kirton. Base map Crown Copyright/database right 2012. An Ordnance Survey/Edina supplied service

3.1 The rune-stone Södermanland 106. Source: Wikimedia commons 
3.2 The rune-stone Södermanland 106. Source:

Riksantikvarieämbetets kulturmiljöbild

3.3 The rune-stones in the eastern part of the Mälar Valley. Source:

Larsson 1990, 39. Reproduced by kind permission of the author

3.4 The runic inscription Södermanland 41. Photo: Bengt A.

Lundberg. Source: Riksantikvarieämbetets kulturmiljöbild

3.5 Södermanland 41 Björke. Photo: Bengt A. Lundberg. Source: Riksantikvarieämbetets kulturmiljöbild

3.6 The bridge of Jarlabanke, in the work of Johan Peringskiöld (1654-1720). Source: Wikimedia commons

3.7 Map of the Lake Edssjön. Source: Fornminnesregistret: Swedish National Heritage Board, National Monument Record, 02-072013. (C) Lantmäteriet I2014/oo601

3.8 Uppland 112: the rune inscription on the west side. Photo: Bengt A. Lundberg. Source: Riksantikvarieämbetets kulturmiljöbild

3.9 Uppland 112: the runic inscription facing south. Photo: Bengt A. Lundberg in late July, 1986. Source: Riksantikvarieämbetets kulturmiljöbild

3.10 Uppland 112: the boulder in its entirety. Source: Riksantikvarieämbetets kulturmiljöbild

3.11 Södermanland 175, Lagnö, Aspö parish. Source: Riksantikvarieämbetets kulturmiljöbild; photo taken by Bengt A. Lundberg

4.1 The Craw Stane Class I Pictish stone and excavations around it. Photos (C) Cathy MacIver and (c) REAP

4.2 Location of key sites discussed in the text. Drawn by Meggen Gondek. Base map: Crown Copyright/database right 2013. An Ordnance Survey/EDINA supplied service

4.3 Invisible messages: stones and their locations. Redrawn by Meggen Gondek

4.4 Sunken elements: stones and their locations. Redrawn by Meggen Gondek

4.5 Thresholds and movement: stones and their locations. Images redrawn by Meggen Gondek

5.1 Map of Co. Clare. Drawn by Clíodhna O'Leary. Base map: Ordnance Survey Ireland 2013

5.2 Plan of Iniscealtra showing main features. Redrawn by Clíodhna O'Leary from de Paor 1997, fig. 2 and Macalister 1916-17, pl. VII

5.3 Inscribed Group 1 cross-slabs. Drawn by Cliodhna O'Leary 117

5.4 A sample of Group 2 grave-slabs. Drawn by Clíodhna O'Leary 
5.5 View of the Saints' Graveyard from the north-west. Photo (c) Clíodhna O'Leary $\quad 126$

5.6 Plan of the Saints' Graveyard. Drawn by Cliodhna O'Leary 127

5.7 Cathasach's Cross. Photo (C) Clíodhna O'Leary 128

5.8 Inscribed cross-base, Saints' Graveyard. Photo (c) Clíodhna O'Leary $\quad 129$

5.9 Composite burial plot, Saints' Graveyard. Photo (C) Clíodhna O'Leary 135

5.10 Group 2 grave-slabs with inscriptions of clerical identity. Drawn by Clíodhna O'Leary $\quad 136$

5.11 Group 2 grave-slab with engraved shoe-prints. Drawn by Cliodhna O'Leary 139

6.1 Map of southern Norway. Drawn by Iris Crouwers 150

6.2 Stone cross, churchyard of Vereide, Gloppen, Sogn og Fjordane. Photo (C) Iris Crouwers 153

6.3 Wooden devotional/mortuary crosses, Herjolfsnes, Greenland. Source: Nörlund, P. 1924. Buried Norsemen at Herjolfsnes. An Archaeological and Historical Study, in Meddelelser om Grønland, LXVII, 1-270

6.4 Lost wooden cross, Giske, Møre og Romsdal. Drawing by Jon Skonvig preserved in manuscript A.M. 370 fol. (c. 1626). Copenhagen, Arnamagnoean Institute, AM 370 fol., f. 23 r. Photo: Suzanne Reitz. Used with permission

6.5 Stone cross from Stavanger. Photo (c) Iris Crouwers, with kind permission of MUST Museum Stavanger, Rogaland 156

6.6 Stone cross from Stavanger. Photo (C) Iris Crouwers, with kind permission of MUST Museum Stavanger, Rogaland 157

6.7 Stone cross from Tjora. Photo (c) Iris Crouwers 158

6.8 Stone cross from Tjora. Photo (c) Iris Crouwers 158

6.9 Stone cross, old churchyard of Njærheim, Hå, Rogaland. Photo (C) Iris Crouwers $\quad 158$

6.10 Map of western Norway. Drawn by Iris Crouwers 159

6.11 Runic cross-slab, churchyard of Grindheim, Etne, Hordaland. Photo (C) Iris Crouwers 162

6.12 Stone cross on burial mound, Hauge, Klepp, Rogaland. Photo (C) Iris Crouwers 164

6.13 Stone cross on natural hill, Gard, Haugesund, Rogaland. Photo (C) Iris Crouwers

6.14 Rune-inscribed lead cross found in prehistoric cairn. Bru, Rennesøy, Rogaland. Photo (c) Terje Tveit, Arkeologisk Museum

7.1 St Madoes cross-slab face A. (c) Perth Museum \& Art Gallery, Perth \& Kinross Council 
7.2. Inchyra symbol stone. (c) Perth Museum \& Art Gallery, Perth \& Kinross Council

7.3 Lethendy Cross-slab, upper half of face A. Photo (C) Mark A. Hall

7.4 Detail of blade-strikes on face A of the Lethendy Cross-slab. Photo (c) Mark A. Hall

7.5 Alex Campbell memorial, Kilchoman Parish church, Islay.

Photo (C) and courtesy Dr David Caldwell

7.6 Memorial to Lieutenant William Keay Falconer, Kinross. Photo (C) and courtesy Mark A Hall

7.7 Memorial to Captain John Fisken Halket, Greyfriars Cemetery, Perth. Photo (c) Mark A. Hall

7.8 Kilwinning War Memorial, Kilwinning Abbey. Photo (C) Mark A Hall

7.9 Crieff Burgh Cross. Photo (C) and Courtesy Perth Museum \& Art Gallery

7.10 The main faces of the Dunning 'Mercat' Cross. Photo (c) and Courtesy Simon Warren, Dunning Parish Historical Society 200

7.11 Forteviot Church banner. Photo (c) Mark A Hall and Courtesy Forteviot Parish Church Kirk Session

7.12 Kettins Cross-slab. Photo (c) Mark A. Hall

7.13 Gask cross-slab, details of modern graffiti. Photo (C) Mark A. Hall 205

8.1 Hunterston Brooch, reverse with runic inscription. Photo (C) National Museum of Scotland

8.2 Killamery Brooch, reverse with inscription. Photo (c) National Museum of Ireland

8.3 Temple Ciarán, Clonmacnoise. The reused slab is positioned third up from the bottom in the right-hand-side door jamb. Photo (C) National Monuments Service, Dept. of Arts, Heritage \& Gaeltacht

8.4 Lion Slab from Temple Ciarán. Photo (c) National Monuments Service, Dept. of Arts, Heritage \& Gaeltacht

8.5 Cross of the Scriptures, Clonmacnoise, c. 909. Photo (C) National Monuments Service, Dept. of Arts, Heritage \& Gaeltacht

8.6 Cross of the Scriptures, east side. Photo (c) National Monuments Service, Dept. of Arts, Heritage \& Gaeltacht

8.7 Base of Market Cross, Tuam, c. 1127. Photo (C) Jenifer Ní Ghrádaigh

8.8 Cross of Muiredach with Adam and Eve scene, c. 900. Photo (c) Jenifer Ní Ghrádaigh

8.9 Cross of Roscrea with Adam and Eve scene, c. 1120-40. Photo (C) Jenifer Ní Ghrádaigh 
8.10 Detail of low-relief foliate ornament, chancel arch, Nuns'

Church, c. 1167. Photo: Jenifer Ní Ghrádaigh

8.11 Clonmacnoise Crucifixion Plaque, c. 1050. Photo (C) National Museum of Ireland

9.1 Ten sub-types of hogback tomb. Redrawn by Howard Williams after Cramp 1984

9.2 Type a hogback, Brompton 17A. (C) Corpus of Anglo-Saxon Stone Sculpture, photographer T. Middlemass

9.3 W. G. Collingwood's illustrations of hogbacks. Source: Collingwood 1927, 165 and 168

9.4 Distribution of sites producing hogbacks. Redrawn with additions by Patricia Murrieta-Flores and Howard Williams after Lang 1972-4; 1984: 86. Base map: Crown Copyright/ database right 2013. An Ordnance Survey/EDINA supplied service

9.5 Brompton cross 1A. (C) Corpus of Anglo-Saxon Stone Sculpture, photographer T. Middlemass

9.6 Type c hogback, Ingleby Arncliffe 4A. () Corpus of AngloSaxon Stone Sculpture, photographer T. Middlemass

9.7 Type k hogback Gosforth 5. Photographs: (C) Howard Williams 2006

9.8 Type b hogback, Aspatria 6A. (c) Corpus of Anglo-Saxon Stone Sculpture, photographer T. Middlemass

9.9 Type g hogbacks from Lowther 4 and Sockburn 21. Source: Collingwood 1972, 171 and Lang $1972 \quad 258$

9.10 Type g hogback from Heysham. Photo @ Howard Williams 2005

\section{TABLES}

3.1 Natural and cultural categories within a $25 \mathrm{~m}$ circumference of 68 rune-stones with known original placing. Source: Klos 2009, 114, author's translation from German

3.2 Natural and cultural categories within a 100 m circumference of 69 rune-stones with known original placing. Source: Klos 2009, 117 , author's translation from German

4.1 Pictish Class I monuments found in or near structures

4.2 Summary of monuments, iconography and structural associations 


\title{
WALKING DOWN MEMORY LANE: RUNE-STONES AS MNEMONIC AGENTS IN THE LANDSCAPES OF LATE VIKING-AGE SCANDINAVIA
}

\author{
ING-MARIE BACK DANIELSSON
}

\section{INTRODUCTION}

\begin{abstract}
rune-stone is defined as a runic inscription found on a worked, - 1 raised and/or transported stone or carved onto in situ boulders or rock outcrops. While the tradition of inscribing stones with runes has preChristian origins back to the Migration Period, the efflorescence in runestones dates to the Late Viking Age (tenth to twelfth centuries). Hence, rune-stones are largely considered Christian monuments (e.g. Gräslund 1991; 1992; Johansen 1997, 159; Lager 2002). After $c$. AD 1120 they were no longer erected and so rune-stones are widely regarded as restricted to a phase of Christian conversion and kingdom formation in which VikingAge society - including patterns of inheritance and identity expression - was in flux (Gräslund 1991; 1992; Zachrisson 1998, 161).

The earlier rune-stones of the tenth and early eleventh centuries tend to carry text only, whereas late eleventh- and twelfth-century runestones were given ornaments and more elaborate zoomorphic images. A Christian faith is expressed through the common symbol of the cross on many rune-stones as well as the contents of some inscriptions expressing formulae and deeds in relation to Christian teaching (Lager 2002). Some rune-stones contain a Christian blessing for the soul of a deceased. Runestones are generally described as memory stones: that is, stones raised in memory of someone who died (e.g. Jesch 2005; Stoklund 2005; Figs 3.1-3.2).
\end{abstract}

From the borders of modern Sweden almost 4000 rune-stones are known (e.g. Samnordisk Runtextdatabas; Klos 2009, 41). Of these, some 1500 rune-stones are found in the county of Uppland, and more than 400 


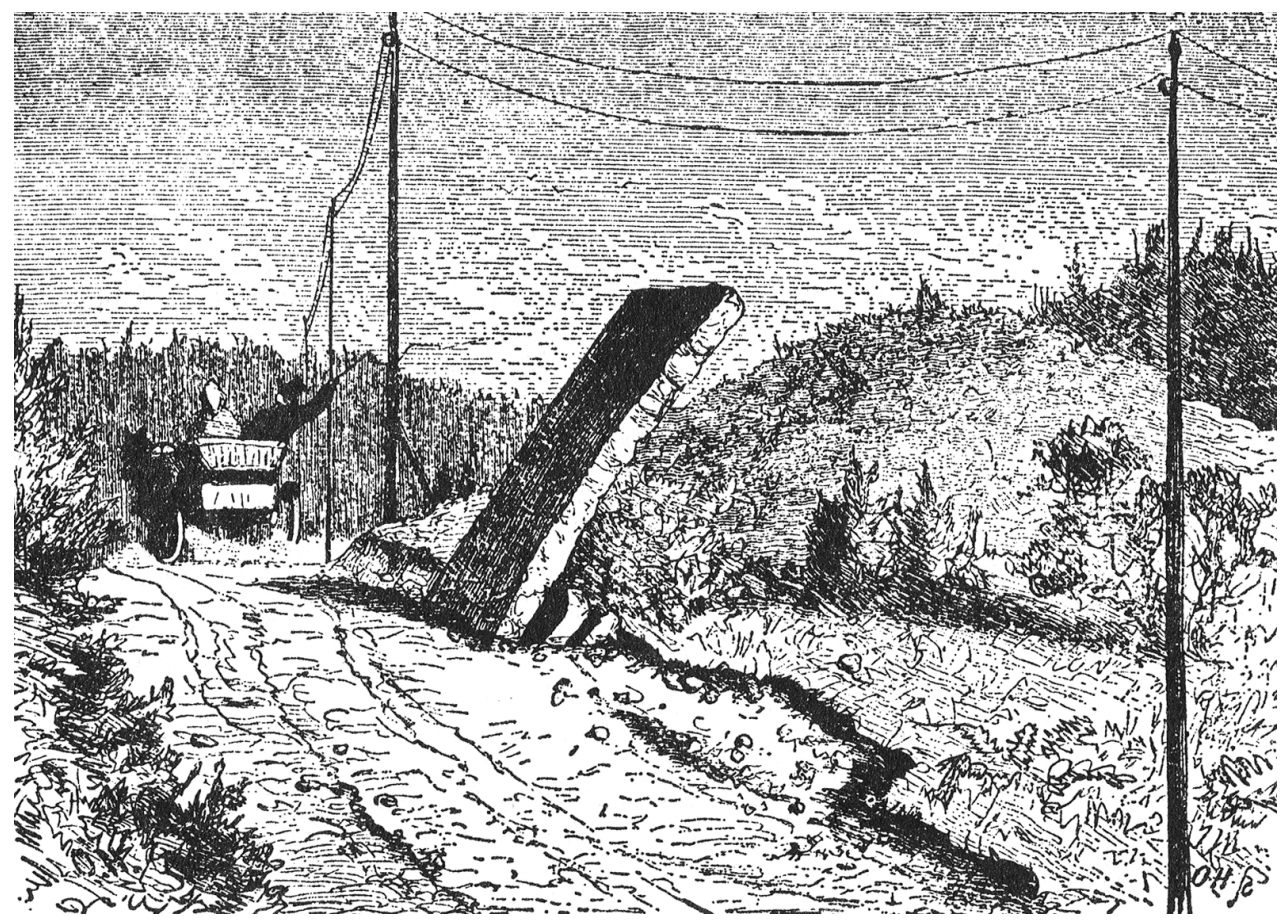

FIG. 3.1 THE RUNE-STONE SÖDERMANLAND 106, KJULA, KJULA PARISH, SÖDERMANLAND, as apprehended in the 1860 s by renowned landscapist Olof Hermelin (1827-1913). The inscription is turned towards the route of travel, and according to the inscription the stone is raised by Alrik in memory of his father Spjut. The stone is more than $3 \mathrm{~m}$ tall (Brate and Wissén 1936).

have been raised in each of the counties of Södermanland, Östergötland and Gotland. A large number of rune-stones in Uppland were erected during the late eleventh and early twelfth centuries (Gräslund 1991; 1992; Zachrisson 1998, 130). These stones belong to the second wave of raising rune-stones, when professional rock carvers arrived on the scene. It has been assumed that the second wave of rune-stone erection is more closely connected to Christianization, perhaps being strongly under the influence of Christian missionaries from Britain and Ireland (Lager 2002, 180-82).

Rune-stones are studied by a number of academic disciplines (for instance, Scandinavian languages, archaeology, cultural heritage management and history of religion), each with its preferred focus, methods and modes of interpretation. Consequently, research questions and interpretations from one specialism are often perceived as inadequate and even unscientific by another academic field. One case in point is the work of Andrén (2000); while he emphasized that text and image upon runestones must be understood visually in relation to one another, runologists have disagreed with many of his suggestions (e.g. Bianchi 2010, 39, 52ff). Another example is Birgit Sawyer's (2000, 92; 2002) interpretation 


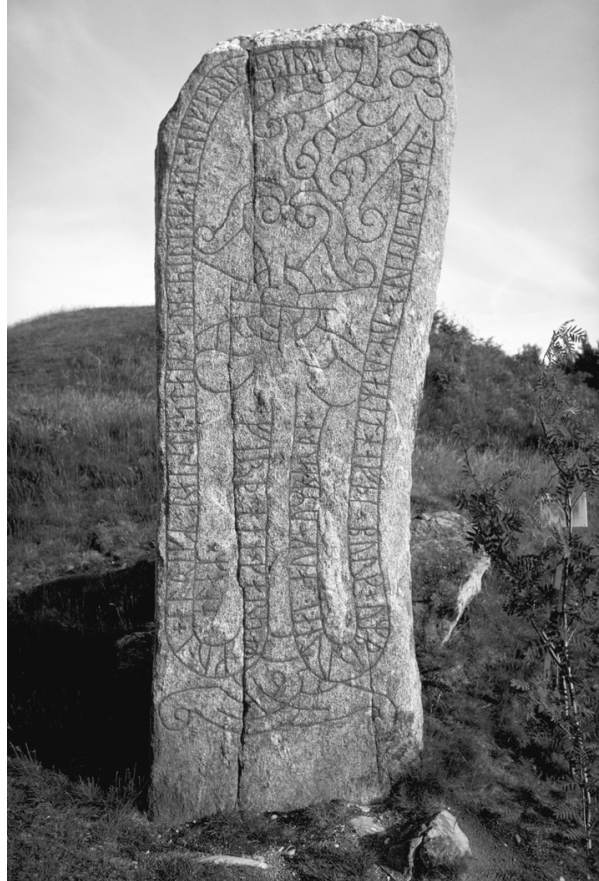

FIG. 3.2 THE RUNE-STONE SÖDERMANLAND 106 photographed around the Midsummer solstice by Bengt $\mathrm{A}$. Lundberg in 1985 of rune-stones as a sign of a higher economic and social status; linguistic scholars have been sceptical and prefer to view the main function of rune-stones as commemorative (Jesch 2005, 95; 2011, 31; Stoklund 2005, 37).

If we accept that rune-stones can be approached with a range of disciplinary perspectives and questions, thus inviting and engendering new and different knowledge production, the archaeological approach adopted here wishes to explore the mnemonic agency of the stones through highlighting some of the myriad rhizomatic relations that were generated through the embodied processes of making, staging and encountering rune-stones. It equally emphasises that memory work is practical, performative and therefore necessarily embodied in its constitution (e.g. Merleau-Ponty 1962; see also Mauss 1992 [1934]). This approach also takes inspiration from feminist theory, which aspires to avoid reducing ambiguity and complexity in interpretations, in this instance regarding how rune-stones were experienced and understood in the Viking Age (Wylie $2007,212-13$ with references). Hence it strives to avoid the impulse to seek interpretative closure regarding what rune-stones 'meant' to Viking-Age 'society'. Thereby, the lived present is seen as an open-ended and generative process (Harding 1987; 1993; Longino 1994, 483). As such, the work is associated to more-than-representational theories that focus on practices and events, which aspires to explore 'new potentialities for being, doing and thinking' in the human past (Anderson and Harrison 2010, 10). It also involves understanding the rune-stones in terms of affect. Affect has been described as ' $t$ t]he pre-personal capacity for bodies to be affected (by other bodies) and, in turn, affect (other bodies). The capacity for affecting and being affected defines what a body is and can do' (Cadman 2009, 456), and in more explicit archaeological works 'affect is understood to be the changes and variations that occur when bodies or forces intersect or come into contact' (Jones 2012, 77). Thus, if rune-stones can indeed be convincingly interpreted as memory stones (Jesch 2005; Stoklund 2005), I want to go 'beyond interpretation' (cf. Alberti et al. 2013). By this I mean that I wish to move beyond decoding runic texts, and further still beyond the study of texts in combination with their ornamentation (following Andrén 2000). Instead I wish to delve deeper into questions concerning the practices and events through which material culture and people were continuously and mutually engaged in the creation and use of runestones. Moreover, I wish to consider how the inclusion of rune-stones in 
the landscape affected human bodies and hence how memory work took place through embodied interaction with rune-stones.

It must be emphasized that the surrounding landscape often constitutes the backbone of the myths of origins that are told or recounted in prehistory, and events in the past are often woven together with the landscape and its different places and features. The narrated past is embodied in the landscape, claiming various monuments and other features as narrative evidence (Chapman 1997; Williams 2006). The landscape therefore has mnemonic qualities and might be regarded as the largest memory prompt of all (Gosden and Lock 1998, 5). Inhabiting the landscape, and performing activities and tasks, is an embodied activity that is constitutive of place (Jones 2006, 212). Therefore, there is a temporality to the landscape; it is processual, ongoing and non-static (Ingold 1993; Bender 2002; Jones 2006, 212). With such foci it is also necessary to recognize that encountering and engaging with rune-stones was not only a process of visual interaction; rather, it involved the entire body, as you perhaps unwittingly were forced to engage with rune-stones in a variety of ways and a variety of locales. In this context it is likewise pertinent to note that it is not a neutral body that experiences and engages with rune-stones. It is necessary to discuss a situated, relational and already oriented body: that is, a body that is situated in, related to and oriented within a number of subject and identity positions tied to, for example, age, ethnicity, sexuality, social position, special position, geographical region and the acknowledgement or rejection of certain mythological and religious ideas (Young 1980; Haraway 1996; Conkey and Gero 1997; cf. Ahmed 2006, 181, note 1). This body is further the subject of sensations (Ingold 2000), and the experiences of these sensations also depend on the body's abilities and disabilities (impaired hearing, blindness, etc.) (e.g. Arwill-Nordbladh 2011). Only the experiencing body remembers and is able to render objects or places meaningful, and repeated encounters with places or objects invokes memories (Van Dyke 2011, 41). Such recognition of memory, emphasizing a sensing, relational and oriented body and person, gives further depths to understanding how and why rune-stones worked as mnemonic agents in the Viking-Age landscape.

To explore this theoretical perspective, my study will focus on case studies from an area with the highest concentration of rune-stones: the eastern part of the Mälar Valley in Sweden (Fig. 3.3). The interpretations of the runic texts discussed below follow the Samnordisk runtext Fornminnesregistret tabas, unless otherwise stated.

\section{RUNE-STONE ENVIRONMENTS AND ORIENTATIONS}

A century ago the professor and runologist Otto von Friesen (1913, 13) remarked that many rune-stones had been moved from their original position. This was undertaken for a number of reasons, he claims, primary among 


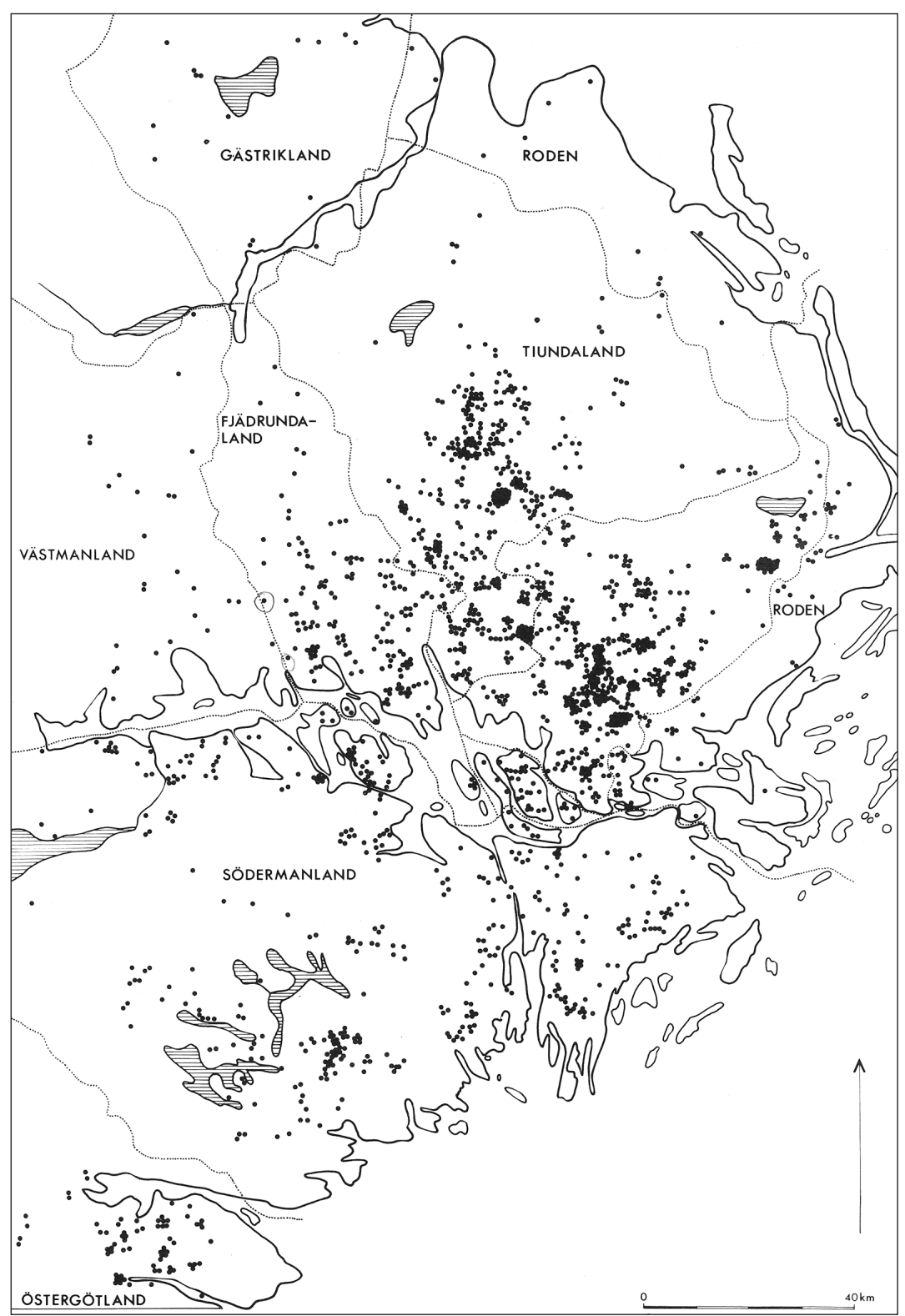

FIG. 3.3 THE RUNE-STONES IN THE EASTERN PART OF THE MÄLAR VALLEY (INCLUDING SÖDERMANLAND, UPPLAND AND PARTS OF VÄSTMANLAND, ÖSTERGÖTLAND AND GÄSTRIKLAND). 
them being that rune-stones were considered useful as building materials. The removal and reorientation of the rune-stones may have started as early as fifty years after the raising of the stones and it continued throughout the centuries until modern times. The earliest reorientation of rune-stones is known from those medieval churches which, still standing today, have had rune-stones inserted in specific places during their construction from the eleventh and twelfth centuries. In fact, the majority of the removed stones can today be found in churches (von Friesen 1913, 12).

Disregarding such potentially disorienting practices (cf. Ahmed 2006), of all the thousands of rune-stones, the original placing of $c .730$ stones can be estimated with some certainty (Klos 2009, 56). By investigating the surroundings and orientations of these monuments, it is possible to get an idea of what kind of place was chosen, and subsequently created, by the rune-stone, and how the rune-stones were meant to affect and direct your body in the landscape. In other words, we need to study what the runestones - as images and as agents - 'wanted' or 'required' of the individual(s) engaging with the monuments in order for the rune-stones to have the desired commemorative affect, or change in relations, upon those encountering them (Mitchell 1996, 76; cf. Langer 1984; Jesch 1998, 462).

Before presenting statistics it is worth mentioning that, early on in the study of rune-stones, researchers observed that rune-stones were raised in connection with historically attested routes over land and water (e.g. Jacobsen and Moltke 1942, 910-11; Ekholm 1950, 140). It was also noted that rune-stones were not constructed in isolation, and equally that they were often raised by cemeteries. Since routes would pass burial grounds, the categories at times overlap. The rune-stones placed by cemeteries would commonly have the carved surface turned towards the routes of travel (Ekholm 1950, 138-9).

Turning to quantitative data, Lydia Klos (2009) has recently investigated the immediate environment of the 730 locatable rune-stones (Tables 3.1 and 3.2). The two tables account for what kind of features are to be found within, respectively, a $25 \mathrm{~m}$ and a $100 \mathrm{~m}$ circumference of the rune-stones. It must be emphasized that the data presented in the Tables and Figures below does not convey the possible experiences a person may have had of the chosen place, nor indeed the multiple qualities of individual locales where rune-stones were situated. This of course includes perceptions of the rune-stone itself, its immediate surroundings and whether both nearby and far-away culturally significant features could, for instance, be seen, heard or in other senses felt when approaching, passing or standing by the stone. Such perceptions could include, for example, a splendid view of a distant mountain, long-range views owing to a prominent geographical location (for instance by a lake, or on a hill), the sound of a rushing stream or the smell of a marshy bog.

From Tables 3.1 and 3.2 it is clear that the most common feature in the vicinity of rune-stones is burials. Other stones are the second most 


\begin{tabular}{lrc}
\hline Category & $-\mathbf{2 5}$ m & \% (of 730) \\
\hline Burials & 243 & 33 \\
Other stones & 158 & 22 \\
No known ancient features & 102 & 14 \\
Creek & 69 & 9 \\
Road & 56 & 8 \\
Bridge & 44 & 6 \\
Border & 35 & 5 \\
Settlement & 26 & 4 \\
River & 16 & 2 \\
Lake & 12 & 2 \\
Place of worship (Bronze Age) & 11 & 2 \\
Spring & 9 & 1 \\
Collapsed dry stonewall & 8 & 1 \\
Assembly & 8 & 1 \\
Bog & 7 & 1 \\
Field & 6 & 1 \\
Single find & 6 & 1 \\
Sea & 1 & - \\
Place of worship (Iron Age [IA], pagan) & 1 & - \\
Place of worship (IA/medieval, Christian) & 1 & - \\
Smith/Craft & 1 & - \\
Hoard & - & - \\
\hline
\end{tabular}

TABLE 3.1. THE DIFFERENT NATURAL AND CULTURAL CATEGORIES WITHIN A 25-METRE CIRCUMFERENCE OF THE 730 RUNE STONES WITH KNOWN ORIGINAL PLACING. (Source: Klos 2009, 114, author's translation from German)

common feature, followed by streams, roads, bridges and borders based on the $100 \mathrm{~m}$ circumference analysis. As remarked earlier, though, the different categories at times might intersect. For instance, rune-stones would be close to both a cemetery and a river, a road would pass a cemetery, a bridge would be close to a border, and so on. In the following, I will discuss what kind of memories may have been associated with the features that are most common in connection to rune-stones.

\section{RUNE-STONES ON BURIAL GROUNDS}

Pre-Christian cemeteries were important arenas for funerals and funeral drama, gathering a great number of people (e.g. Price 2010). The construction of the pyre and the subsequent conflagration formed a major spectacle (Williams 2004), and could involve a display of an array of material culture, with, for example, the corpse dressed up in special clothing. In some instances, the ritualized killing of individuals took place; these were 


\begin{tabular}{lcc}
\hline Category & -100 $\mathbf{~}$ & \% (of 730) \\
\hline Burials & 389 & 53 \\
Other stones & 208 & 29 \\
Creek & 191 & 26 \\
Road & 111 & 15 \\
Bridge & 79 & 11 \\
Border & 70 & 10 \\
Settlement & 65 & 9 \\
River & 45 & 6 \\
Lake & 39 & 5 \\
Place of worship (Bronze Age) & 29 & 4 \\
Collapsed dry stonewall & 27 & 4 \\
Field & 27 & 4 \\
Single find & 23 & 3 \\
Spring & 13 & 2 \\
Bog & 11 & 2 \\
Assembly & 8 & 1 \\
No known ancient features & 6 & 1 \\
Place of worship (IA/medieval, Christian) & 6 & 1 \\
Sea & 4 & 1 \\
Hoard & 3 & - \\
Place of worship (IA, heathen) & 2 & - \\
Smith/Craft & 2 & - \\
\hline
\end{tabular}

TABLE 3.2. THE DIFFERENT NATURAL AND CULTURAL CATEGORIES WITHIN A 1OO-METRE CIRCUMFERENCE OF THE 730 RUNE-STONES WITH KNOWN ORIGINAL PLACING. (Source: Klos 2009, 117, author's translation from German)

sometimes cremated with the deceased or disposed of in other ways (Back Danielsson forthcoming). Consequently, memories associated with cemeteries would have been strong and dramatic as well as cumulative. However, since ordinary roads and routes were commonly associated with cemeteries (e.g. Engesveen 2005), the burial grounds were also passed on a regular perhaps daily or weekly - basis despite a frequent absence of funerals.

Equally important, burial grounds were places that people would visit even though no funeral or burial was imminent or taking place. Within Late Iron Age Scandinavian contexts there are several indicators that the deceased or created being/ancestor that dwelled in the burial mound had agency and was considered capable of communication. This is supported by the opening of burial mounds, but also by medieval sagas, Edda poems and laws, since they frequently refer to communication between living and dead beings (Brendalsmo and Røthe 1992, 102; Gansum 2004a and b). Furthermore, the Christian Gulating Law from the mid-thirteenth century $\mathrm{AD}$ strictly forbade (heathen) activities such as grave-digging, 


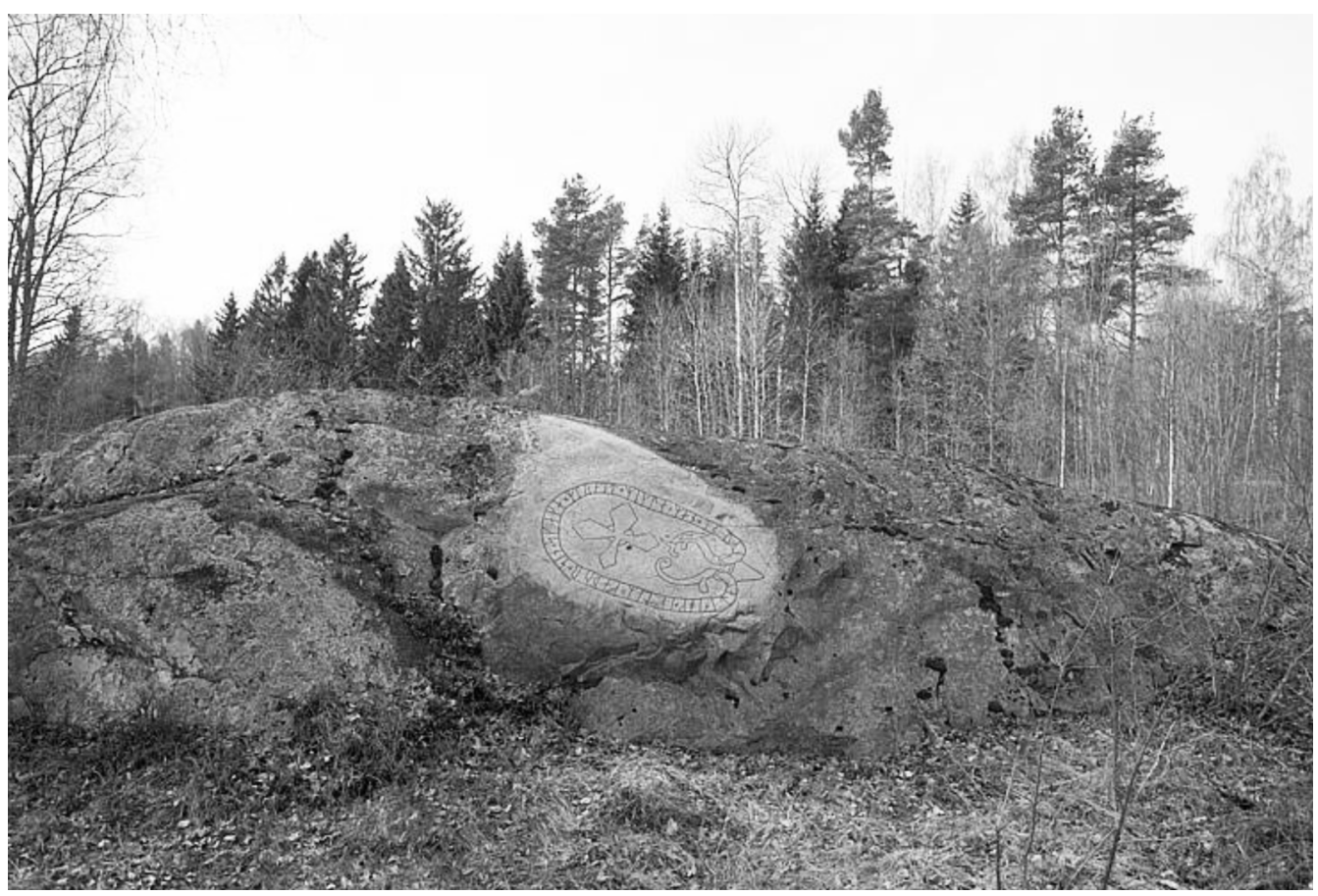

FIG. 3.4 THE RUNIC INSCRIPTION SÖDERMANLAND 41 FROM BJÖRKE, VÄSTERLJUNG PARISH, PHOTOGRAPHED IN LATE

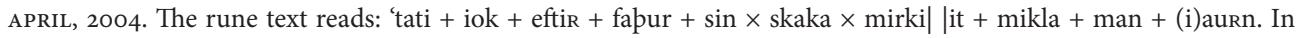
English: Tati/Tatti cut the great landmark in memory of his father Skakki/Skagi; may...'

sitting on mounds and asking questions about the future or reasons for mishaps (e.g. Breisch 1994). The cemetery was thus a significant place for various exchanges, communicative acts and reciprocal engagements on both an individual and social level that involved the past, the present and the future. It is at such mnemonic multi-dimensional hot-spots that rune-stones were situated or runic inscriptions were added to a boulder or outcrop. It has been suggested that equipping such a place with a runestone bearing a cross was a way to give the heathen burial ground a Christian inauguration (Gräslund 2001, 42). Be that as it may, of interest here is how the relationship to the place, and by extension memory work, was altered through the rune-stone or runic inscription, and how it enabled a reconfiguration of existing uses and meanings. Therefore, we must recognize that rune-stones with carved and painted texts, images and ornamentation are evocative and demand attention, forcing one's body to behave, and be oriented, perhaps even disoriented, in certain ways. As images, rune-stones affect and engage the beholder, and they are actively entangled in social structuration (Mitchell 2005; Jones 2007; Back Danielsson et al. 2012, 5-7). As such, the rune-stones introduce phenomenological registers that exceed the thought of rune-stones as encoded statements or representative of Christian inaugurations. 


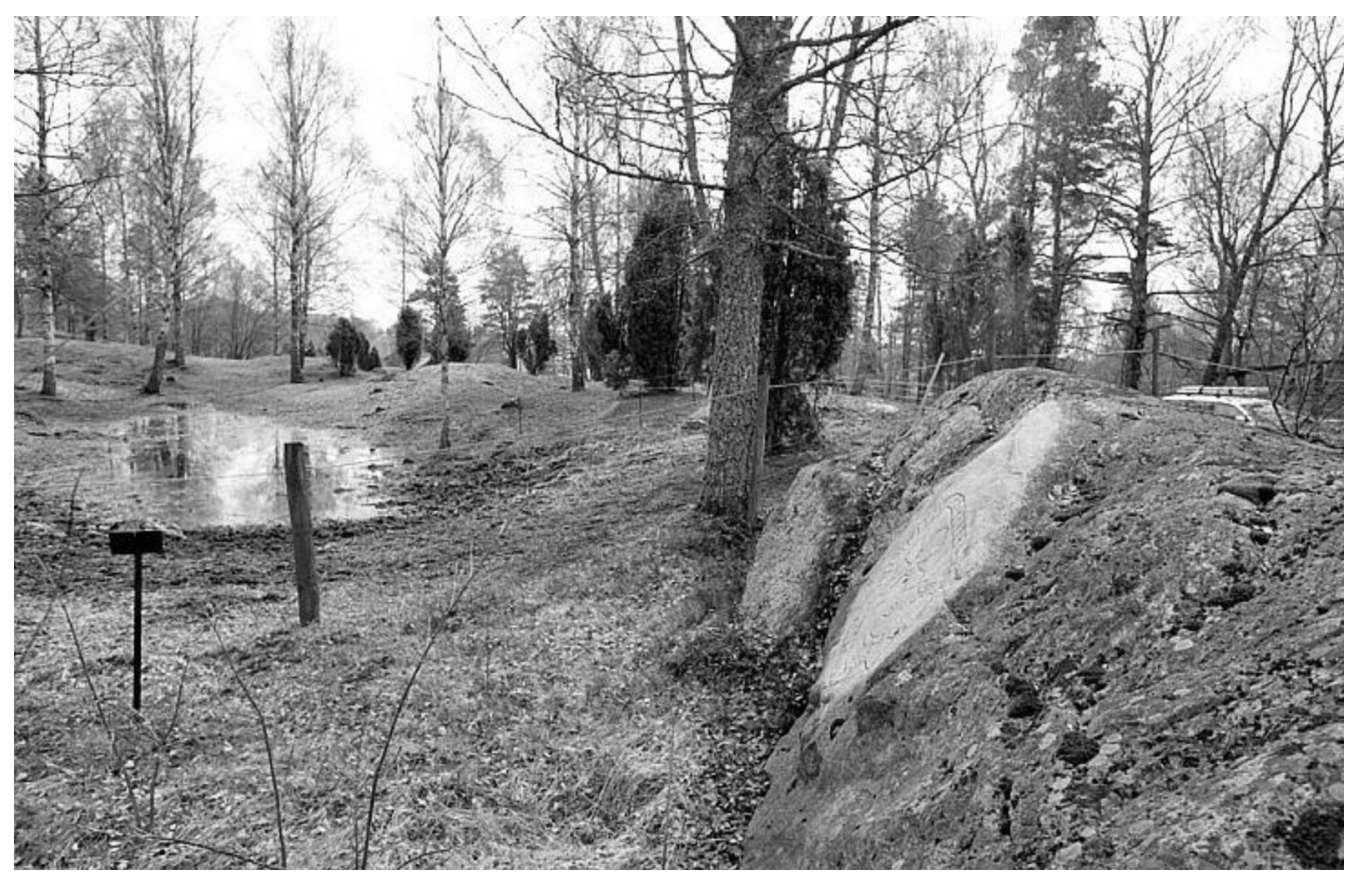

FIG. 3.5 SÖDERMANLAND 41 BJÖRKE, VÄSTERLJUNG PARISH, WITH SURROUNDING MOUNDS, PHOTOGRAPHED IN LATE APRIL, 2004. The boulder on to which the runic inscription is made is in a large cemetery, and it is surrounded by at least forty mounds, 180 circular stone settings, two tricorn stone settings and a ship respectively as well as one raised uninscribed stone (Fornminnesregistret).

Figures 3.1, 3.2, 3.4 and 3.5 are examples of runic inscriptions in cemeteries, where the burial grounds have been in use for a considerable amount of time prior to the inscriptions. While the runic inscription Södermanland 41 (Figs 3.4-3.5) follows the elongated stretch of the boulder by being inscribed at an oblique angle, the tall rune-stone Södermanland 106 (Figs 3.1-3.2) seemingly echoes the size of the large mound by which it was raised. Its large size (more than $3 \mathrm{~m}$ tall) must have required a tip-toe position (to say the least), or perhaps being mounted on a horse, in order to be able to read or study the runic ribbon. However, both runic inscriptions, as indeed every other writing, require that you have to twist and turn your body to follow and read the inscription of the snake loop. Such bodily acts prolonged your stay by the monument - they promoted embodied engagement with it, and consequently facilitated the memory process.

\section{OTHER STONES IN THE VICINITY OF RUNE-STONES}

Early on, researchers remarked that rune-stones were not made to stand in isolation (Jacobsen and Moltke 1942, 998-9). From Tables 3.1 and 3.2 we can see that the category 'Other stones' is the second most frequent category associated with rune-stones. In fact, rune-stones themselves at times 


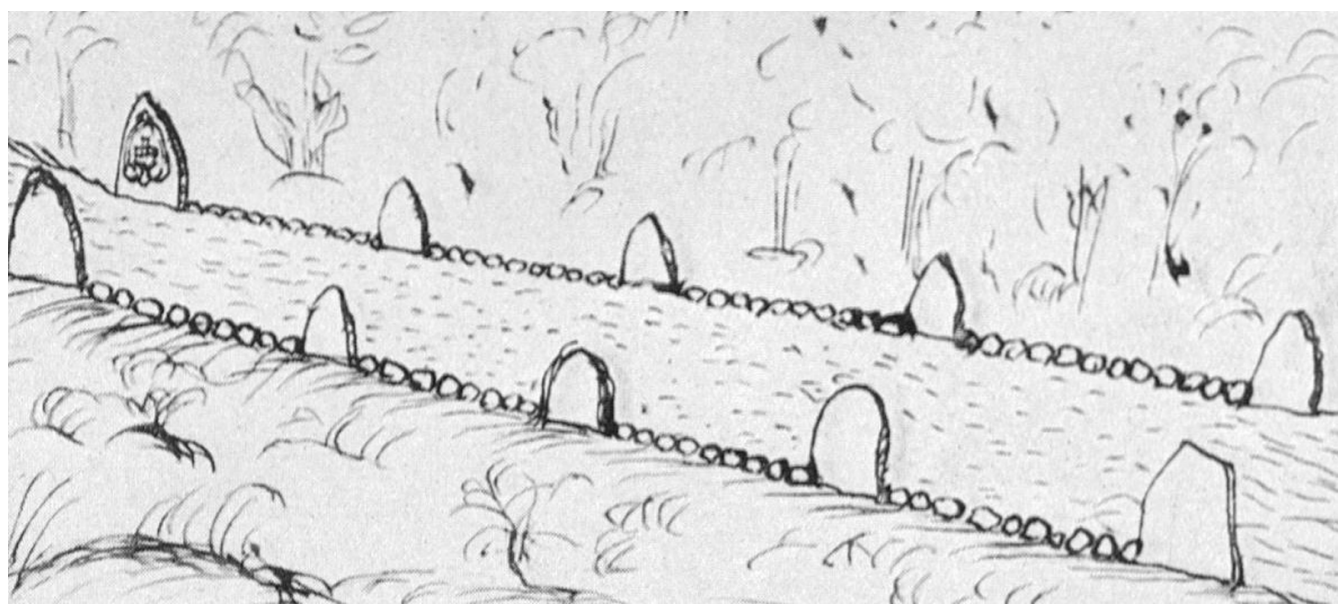

FIG. 3.6 THE BRIDGE (OR RATHER EMBANKMENT) OF JARLABANKE AS IT APPEARS IN THE WORK OF JOHAN PERINGSKIÖLD (1654-1720). declare that they are part of a monument comprising several stones. This is, amongst other things, evident through the usage of the word kuml, which can refer to the rune-stone itself and, when written in the plural, to other stones that were erected at the same time. Importantly, the word kuml on rune-stones could also refer to a burial mound: that is, the tenement of the dead mentioned in the runic inscription (Back Danielsson 2007, 152).

A single rune-stone may have affected, and in some instances perhaps controlled, movement in the landscape. Moreover, by arranging several stones in certain patterns the way one's body approached a rune-stone and/ or a border, a destination, a resting place, was even more controlled and perhaps perceived as predestined. This force of regularity in combination with repeated performances builds memory. Accompanying stones could be standing in one or two rows (e.g. Da 30 Bække 2), in circles (e.g. Da 282-6 Hunnestad, Da 334-5 Västra Strö, Da 357 Stentoften) or in the shape of a ship (e.g. Da 209 Glavendrup, Da 230 Tryggevælde). Other examples from the county of Södermanland are the rune-stones Södermanland 34 and 35, which frame a road in immediate connection to a river (Brate and Wessén 1936). Another example is the well-known Jarlabanke monument (Fig. 3.6), from the county of Uppland, where several stones, both inscribed (for instance, Uppland 164 and Uppland 165) and uninscribed, are aligned on both sides of a path or a road (Snædal Brink 1981, 129). Yet another illuminating example is the rune-stone at Ängby in Lunda, Uppland, carved by Asmund Karesson (Ekholm 1950, 138-9). Ängby had one of the biggest cemeteries in the county and close by the rune-stone and cemetery were land routes and waterways. During excavation it was discovered that this stone constituted the centre of fourteen flanking bautas (bautas are large uninscribed standing stones) and that one end touched an ancient ford. At Anundshög, in the county of Västmanland, a line of raised stones follows a prehistoric road and ends at an ancient ford. In front of the big mound 


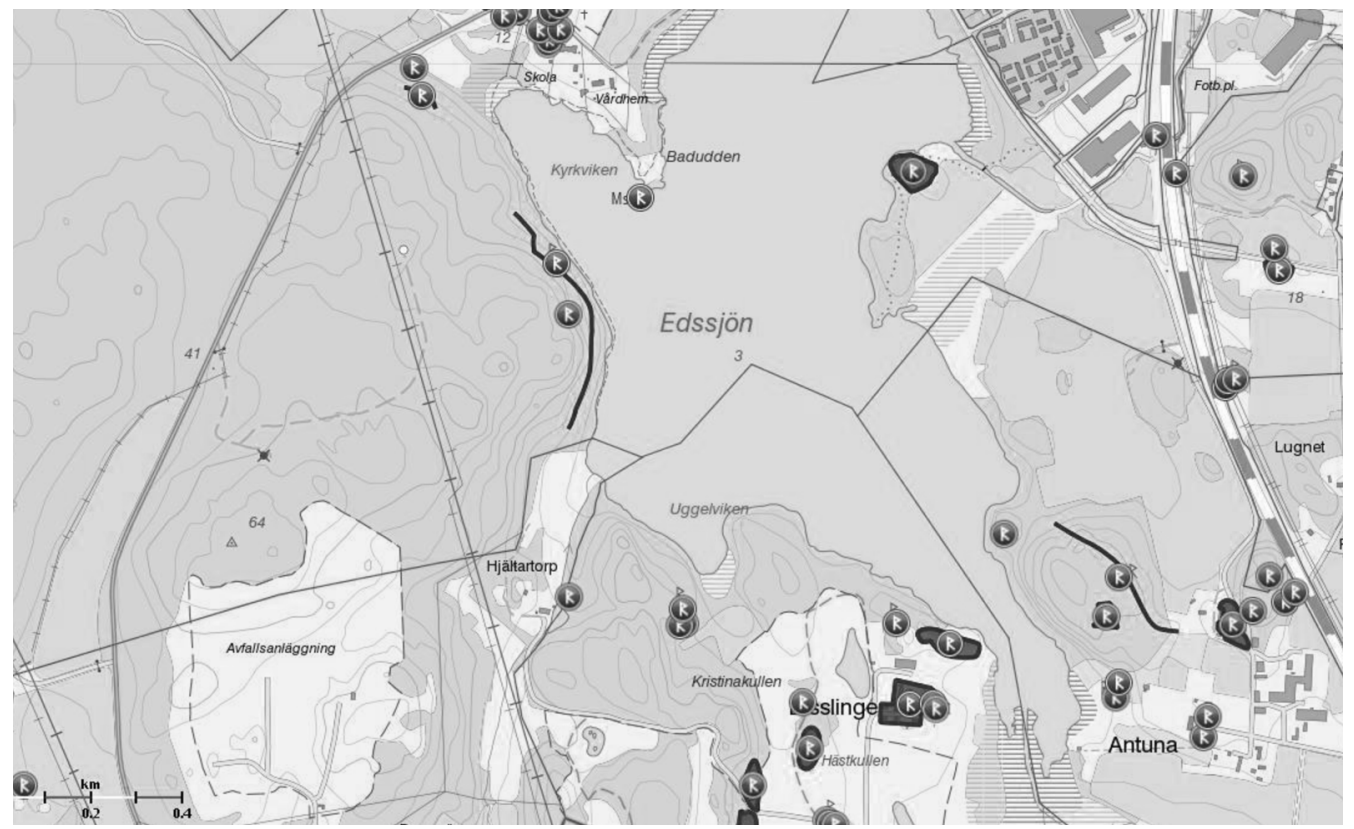

FIG. 3.7 MAP OF THE LAKE EDSSJÖN WITH THE ANCIENT ROAD MARKED WITH A BLUE LINE AND AN 'R', FOUND ON THE WEST (LEFT) SIDE OF THE LAKE. The boulder with the two runic inscriptions (Uppland 112) is found by the northern 'R'.

called Anundshög, which served as an assembly place well into the Middle Ages, the line of vertical uncarved stones is interrupted by a carved runestone (Antiquarian Topographical Archive).

\section{RUNE-STONES BY BORDERS AND BY LAND AND WATER ROADS}

Rune-stones were often sited by borders. Such borders or cross-roads were points of intersection that were given significance throughout the Iron Age in Scandinavia. This is demonstrated by, for instance, the deposition of hoards of gold (Wiker 200o), silver (Zachrisson 1998) and currency bars of iron (Lindeberg 2009) at these junctions. Placements of weapons and other items have also been retrieved in the vicinity of bridges (Lund 2005). These bridges were built before later Christian bridges, whose constructions were considered to be examples of good deeds executed, enabling people to travel in the landscape more easily (Lund 2005). By placing rune-stones at, or by, cross-roads, memory work would be facilitated. Meanwhile, accompanying aligned stones controlled movements, forcing individuals or groups to move in certain directions.

I have already mentioned that paths or roads, whether by land or water, often passed burial grounds (e.g. Fig. 3.1). Yet, of course, there are also examples of roads or paths that do not pass cemeteries and yet have been considered appropriate places for runic memorials. One such is the runic 

INSCRIPTION ON THE WEST SIDE OF THE BOULDER PHOTOGRAPHED IN LATE JULY, 1986. The text reads in English: Ragnvaldr had the runes carved; (he) was in Greece, was commander of the retinue.
FIG. 3.8 UPPLAND 112: THE RUNE
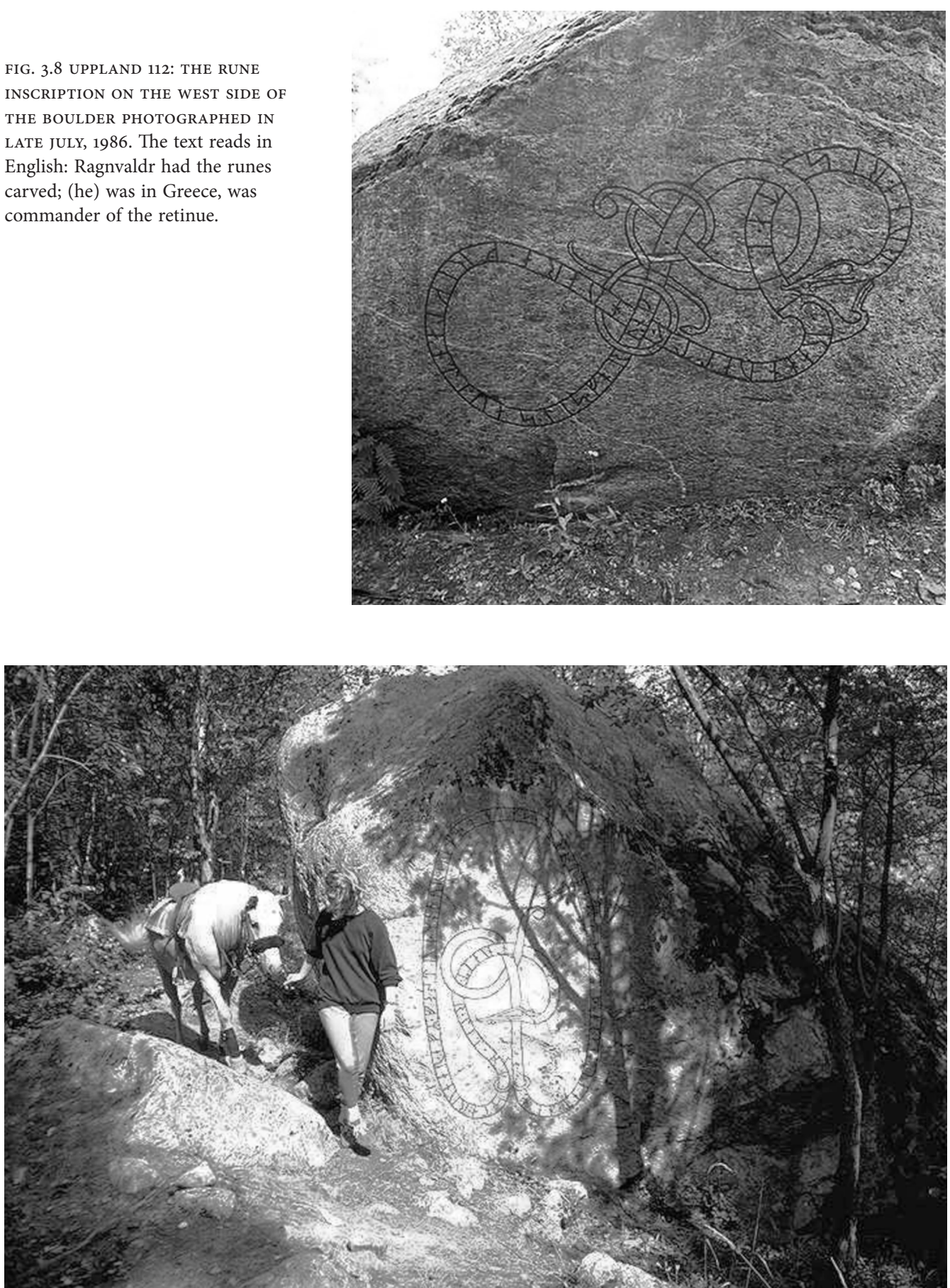

FIG. 3.9 UPPLAND 112: THE RUNIC INSCRIPTION FACING SOUTH. Note the narrow passage of the path/road just by the boulder and the runic inscription, forcing you to close encounters. The text reads in English: Ragnvaldr had the runes carved in memory of Fastvé, his mother, Ónæmr's daughter, (who) died in Eið. May God help her spirit. 


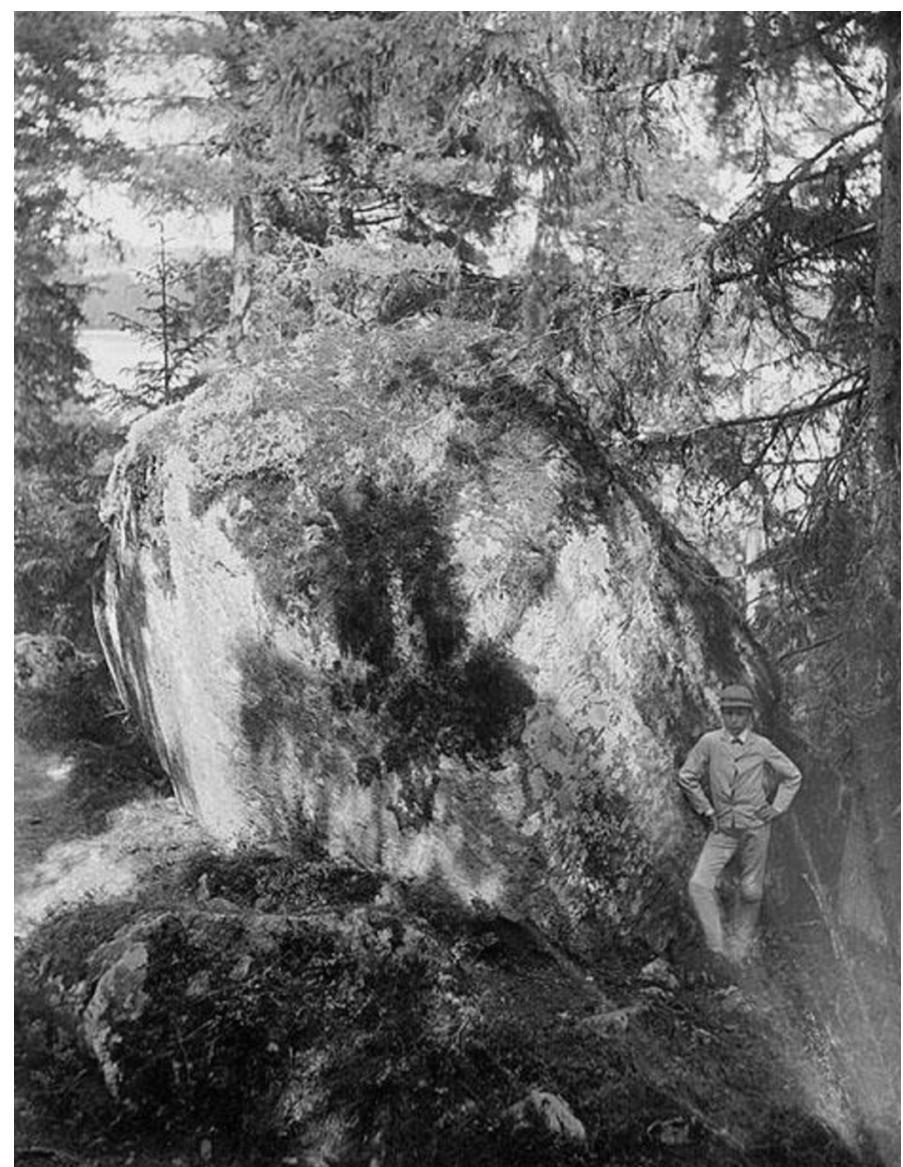

FIG. 3.10 UPPLAND 112: THE BOULDER IN ITS ENTIRETY. The stone/smaller boulder opposite the large boulder's rounded or pointed corner is in this photo covered with moss but clearly seen in Fig. 3.8. Also note the Lake Edssjön in the background (upper left corner). The boy, standing by the inscription to the south, is no other than Sigurd Curman (1879-1966), who later became General Director (19231946) of the National Heritage Board. Curman's father, Carl $\left(1833^{-1913)}\right.$, is the photographer.

inscription Uppland 112 in the parish of Ed, Uppland. Uppland 112 really consists of two separate inscriptions made on opposing faces of the same boulder (Figs 3.8-3.10) located on a path or a road that more or less follows the western stretch of Lake Edssjön (Fig. 3.7). This path or road allegedly connected the harbour of Edsbacka with the northern area of Lake Edssjön that in medieval times also received a church (Eriksson 1982, 41-5).

It is pertinent to note that each inscription is seemingly executed in such a fashion that it follows and fits the form of the boulder. Coming from the north - thus heading south - you would encounter the monument as shown in Figure 3.8. This part of the boulder is fairly low, and therefore, I argue, the inscription's snake/animal/beast appears to lie down and seemingly follows the pathway. On the other hand, if you came from the south, you would meet the more typical, seemingly portal-like, inscription (Fig. 3.9; cf. Andrén (1993) who interprets Gotlandic picture stones as symbolic doors to other worlds). This portal-like execution of the inscription is apparently allowed or dictated by the boulder's particular shape or form facing south. 
The two inscribed sides face different directions and can thus therefore not be seen simultaneously by a person travelling on the path. When you have passed one inscription the path narrows owing to the fact that the space between the inscriptions is somewhat rounded or pointed (the boulder almost has a gable), and opposite this 'gable' another stone or smaller boulder is found on the surface of the ground. These features turn the pathway into a veritable threshold, or indeed a very narrow passage, as seen in Figure 3.10. This narrowing of the path forces your body to come very close to the boulder and its inscriptions.

\section{RUNE-STONES AS MATERIALS OF AFFECT}

Leaving the surroundings of rune-stones and turning our attention more intensely to the rune-stones themselves, I argue that the stones are examples of multi-media, demanding the evoking and engaging of an array of bodily senses. The size of the rune-stone - whether life-size or at times in more gigantic (Fig. 3.1) or miniscule form - is of course important when discussing affect. Equally affective is the choice of stone material, the stone's surface, contour and colour. The rune-stones as images worked as focal points that transformed the place and affected your directionality in the landscape. At times such qualities were aided by the narrowing of a path or a road, for instance through the building of a bridge or an embankment, or by making runic inscriptions at places with threshold qualities (for example, mentioned earlier, Uppland 112), by which you would be forced into close encounters. As remarked earlier, in order to engage with them properly - to read the runes, for instance - one would have to twist and turn one's head/body to be able to follow the runic ribbon. This is very different from continental Christian monuments carrying texts written horizontally in Latin with imagery inspired by the Bible (Lager 2002). The words are equally interpreted as being placed in specific relations to the imagery/ornamentation of the stone, thus demanding that text and image must be understood visually in relation to one another (Andrén 2000; cf. Lund 2005; Bindberg 2006).

It is generally assumed that rune-stones were painted in different colours (Jansson 1984, 167). Deleuze $(1986,118)$ has argued that colour is an affect itself and Jones $(2012,76)$ has demonstrated how colour has an affect that goes beyond the material. The most common shades used on rune-stones were black and red, but brown and white are also known to have been employed (Jansson 1984, 167; Tronner et al. 2002). It must be remembered, however, that these colours, owing to their chemical composition, may have been the ones best preserved (Tronner et al. 2002); that is, other colours may have been common, but have left no traces. Even so, it would not be surprising if red and black were most commonly used since they, together with white, have been found present as primary colours in many cultures (e.g. Douglas 1966; 1970). The rune-stones themselves also occasionally 
declare that they have been painted (Södermanland 205, 347, 213 and Öland 43 (Peterson 1994)). The rune-stone (Gotland 203) from Hogrän church, Gotland, likewise declares that it has been painted, or, rather, it is described as 'illuminated' (Johansen 1997, 6; Lindqvist 1941; 1942). More specifically, the rune signs are at times declared to be painted red, as is stated on the inscription Södermanland 206 (Jansson 1984, 161-2). The colours were used to aid reading and deciphering the text and images in equal measure.

The colours made rune-stones eye-catching, but what memories could have been evoked by red and black? It has been suggested that the colour red was associated with blood, struggle and sacrifice in the Viking Age (Gansum 1999, 456). Through its association with blood, red was also related to family. It is worth pointing out that the concept of the family was used to connote and structure Viking-Age society. The ancient Swedish word ätt stands for family/kinship (Hellquist 1980), and it is commonly family relations that are expressed on the rune-stones. The concept of ätt can be traced to at least the beginning of the ninth century, and is also linked to the German aihti and the Gothic word aihts, meaning property (Hellquist 1980). The ätt functioned as the social foundation of society through systems of loyalty and cult practice (Lamm 1995; cf. Hafström 1982; Fenger 1982; Hamre 1982; Lindal 1982). The same word was also used for the three groups of letters that made up the futhark, the runic alphabet, where each ätt consisted of eight (ätt) letters (Gustavson 1995). Importantly, the word ätt also stood for the cardinal points of the compass (Hellquist 1980). Consequently, through the colour red, the runic signs, and by extension the word ätt, there is a linkage between bodies and their orientation in the landscape. As a result, an 'ancestral geography' (cf. Edmonds 1999) was conveyed through the runic inscription.

The colour black, in contrast, has been argued to be associated with Ragnarok, Utgard, night, travel, knowledge and sejd (prophesy making) (Gansum 1999). The interpretations of colours presented here are all taken from analyses of Norse literature. Of course, they need to be complemented by other possible interpretations, but nonetheless, they indicate how colours as affects were important in the work of memory.

In this context the play of light on monuments must also be discussed. Both shadow and light create dynamic and interactive experiences, as recently highlighted and demonstrated by Jones on rock art images in the region of Kilmartin, Argyll, Scotland (2012). Consider Figures 3.8, 3.9 and 3.11, which depict two runic inscriptions on the boulder by Lake Edssjön. When the boulder was photographed, the western inscriptions - the seemingly coiled up snake - rests in the shadow, the southern inscription bathes in sun-light. There is thus an ongoing performance, a play of light and shadow making the runic inscriptions visually stronger and weaker depending on season, time of day, weather conditions and the direction from which they are seen. These properties also create pace and rhythm to travels within the landscape. 


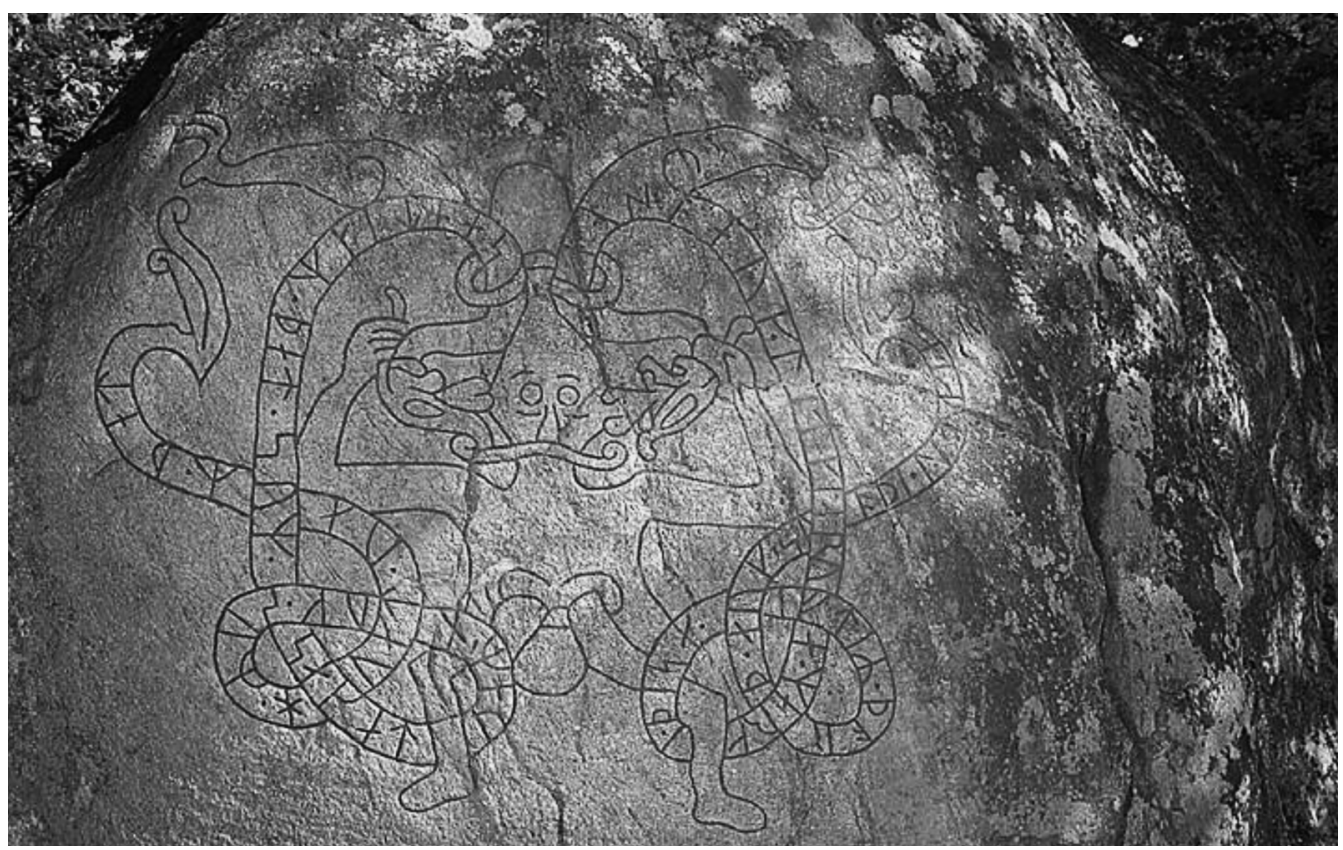

FIG. 3.11 SÖDERMANLAND 175, LAGNÖ, ASPÖ PARISH. The figure is seemingly holding two snake/lizards' heads in each hand, close to his/her ears, perhaps implying that the runic letters, the carvings, in fact are to be uttered as sounds. The text reads in English: Gíslaug had these landmarks made in memory of Thórðr, also Slóði had (them) made. It is true that which was said and which was intended. (Brate and Wissén 1936, 139, Samnordisk runtextdatabas).

Not only were rune-stones connected to colours, shadow and light but also, I argue, to sounds: they were meant to echo into the future. This is really self-evident, since the runic letters were not simply meant to be read but were probably also situated so as to be read out loud. One example, the aforementioned Södermanland 41 from Björke (Figs 3.4-3.5), has a runic inscription at the end that expresses that 'it should always be heard' (Brate and Wessén 1936, 31, my translation). In Gotland, Hogrän (Gotland 203), the runic ribbon is described as 'Ormalur' (translated to snake-loop by the Samnordisk runtextdatabas), where lur in Ormalur corresponds to the horn or lure of the snake - thus the medium for written and oral messages (Johansen 1997). Perhaps the rune-stone Södermanland 175 from Lagnö, Aspö parish (Fig. 3.11), demonstrates through its imagery the idea that the signs in the snake's bodies correspond to sounds or words, since the two lures are held close to the depicted person's ears.

\section{THE MATERIALITY OF STONE AND IMAGES}

What relations were there with the material stone during the Viking Age? Needless to say, stones, rocks, boulders and mountains were given significance far earlier in Scandinavian prehistory. Occasional Iron Age mounds had an uncarved stone erected on their tops. Furthermore, during the Iron 
Age a common idea was that dead kinfolks were believed to dwell and live in stone/mountains. In fact, both the mound and the mountain were considered tenements of the dead (Johansen 1997), contributing to the fluid biographies of the rune-stones (cf. Jones 2007, 216). I have already mentioned how the word $\mathrm{kuml}$, used on rune-stones, could signify both a mound and a (rune-) stone. Indeed, kuml, as signs, thus could be said to direct both living and dead bodies to their designated destinations (Back Danielsson 2007, 163-4).

Mitchell (2005) has described pictures as animated beings, and I believe that rune-stones, as images, were/are equally so. Rune-stones were often of comparable stature to people, and their silhouettes could have reminded the viewer of a person waiting for them, imbued with stories or something to behold. The stone itself, whether chipped from rock or a natural boulder, demanded certain actions from the carvers, and later from the readers or those engaging with them. Returning to the Södermanland 41 inscription (Figs 3.4-3.5), it was made on a boulder, and it follows the elongated stretch of the boulder. Otherwise, most runic inscriptions stand up, as in Figure 3.1. However, that is not because such a position was considered the right one, but rather because the stone or boulder onto which the inscriptions were made were considered endowed with such material properties or characteristics that it demanded the inscription to be executed in such a way. Subsequently, the runic ribbon seemingly always follows the contours of the stone, whether chipped from rock or free-standing small or large boulders (see, for instance, Figs 3.1, 3.4 and 3.5). To paraphrase (and answer) both Mitchell (2005) and Gosden (2005), it was what the stone wanted, what it demanded through its materiality.

\section{FIRST-CLASS TRAVELLING AND COMMON FOOT TRAFFIC}

Rune-stones, when seen as memory stones, were raised in memory of someone who died, and they frequently declare a person's place of death. Such places are predominantly faraway places such as Greece, England, Denmark and Gotland (e.g. Larsson 1990). In fact, rune-stones often tell of journeys made afar, but also how certain people constructed bridges and owned villages, who inherited what, who died how, who had been where and whose souls were deserving of paradise (see examples in Samnordisk runtextdatabas). These all seem like individual stories, but they were commemorative for society as a whole. Rune-stones with such stories were placed where people repeatedly walked, met, and travelled. Commemorative practices are performative and recurring in nature (Connerton 1989), which is why it is important to point out that it was not only the runestone carvers/erectors that travelled in the landscape. Rather, we must envision different classes and genders inhabiting the landscape, perhaps transporting things, goods, people and/or information or stories from one place to another (e.g. the aforementioned runic inscription Uppland 
112, Figs 3.7-3.10). This is perhaps an obvious statement, since the power relations expressed by rune-stones must be implemented where they can have an impact on people, in this case on roads and routes where people commonly travelled; more specifically at junctions or cross-roads where people perhaps were 'forced' to rest, or slow down, on their journeys. Such a practice-based approach serves to create a more dynamic perspective on the rune-stones as monuments, and how these actually linked people together and thus are coupled not only to presumed elites or people who belonged to an upper-class stratum of society (Van Dyke 2011, 43).

\section{CONCLUSIONS: RUNE-STONES AS MNEMONIC AGENTS}

By raising stones, both carved and uncarved, long-term social memory was created. As Joyce (2003) has noted on monumental structures in Mesoamerica, this meant an evocation of timelessness and permanence. The same is true for rune-stones - they were oriented towards the future (Jesch 1998; 2005, 95) while at the same time their placing connected to, and echoed, past activities. Rune-stones thus held a general mnemonic function as fields of social memory. While at the same time expressing individual memories, these were inserted into social memory, gaining meaning and enabling renegotiations and hence change in general memory itself.

Rune-stones were individual expressions in the sense that they often reiterated the faiths and deeds of a deceased person and his/her relatives. However, it must be pointed out that individual memories would not exist were it not for social memory, which provides a foundation and context for them (Middleton and Edwards 1997). Social memory here refers to the 'selective preservation, construction, and obliteration of ideas about the way things were in the past, in service of some interest in the present' (Van Dyke 2011, 37). This definition demonstrates that social memory legitimizes current power relations, which is accomplished in a number of ways. Importantly, rune-stones are raised at past places of importance, such as at cemeteries. In some instances they have been situated also at new places that are cloaked or rearranged to be similar to, and remind people of, prominent past places (e.g. Norr and Sanmark 2008 on certain assembly places). Through such usage, a rune-stone both reminds people of the past while at the same time bringing something new to the equation. It is an index of memory; the rune-stone can evoke remembrance, but can equally be called a mnemonic citation (Jones 2007, 24, 26, 55).

In this paper I have shown that in order to understand how rune-stones worked as mnemonic agents it is useful to introduce the concept of affect. Memory work is practical, performative, experiential, profoundly material and very much an embodied process. Therefore, affect is an appropriate concept since it highlights the changes and variations human bodies may have experienced when rune-stones were created and/or encountered. The 
sight of dazzling colours and the play of light and shadow and enticing sounds are some of the possible sensations evoked by the stones, perhaps forcing people into close encounters. I have also mentioned that the size of rune-stones had affective dimensions. Altogether a rune-stone can be seen as an animated being that wanted something from those who engaged with it (cf. Gosden 2005; Mitchell 2005). Furthermore, in order to read and engage with the interacting and meandering texts and images, the body had to twist and twirl, also prolonging the interpreter's stay by the monument. I have equally emphasized that rune-stones rarely stood alone, and that it is important that the stone's relation to other stones is considered. The stones together structured the landscape in a certain way, and also regulated how the body was to enter, encounter and experience this index, nexus, or gate to other worlds. I have also maintained that not only places but also families were tied together in the landscape through the rune-stones. They resulted in shared experiences of landscape, life and death - that is, commemoration. In this way, individuals, collective memory and rune-stones were seamlessly interwoven (cf. Connerton 1989; Halbwachs 1993).

\section{ACKNOWLEDGEMENTS}

First of all, my thanks go to the editors for inviting me to participate in this inspirational volume and for their valuable comments on an earlier version of the paper. Thanks are also due to the two anonymous referees, as well as to the Birgit and Gad Rausing Foundation. I am grateful to Dr Charlotta Brohult for curing me from an 'aptypical infection' that took months to recover from. I am also thankful to Anders Carlsson and Fredrik Fahlander for reading an earlier version of the manuscript. Many thanks go to Ben Alberti for reading and making valuable comments on a very early version of the paper. Lastly, heartfelt thanks to Per and Milton for their never-failing support.

\section{BIBLIOGRAPHY}

Ahmed, S. 2006. Queer Phenomenology: Orientations, Objects, Others, Durham: Duke University Press

Alberti, B., Jones, A. and Pollard, J. 2013. Archaeology after Interpretation. Returning Materials to Archaeological Theory, Walnut Stream, California: Left Coast Press

Anderson, B. and Harrison, P. 2010. Taking-Place: Non-Representational Theories and Geography, Farnham: Ashgate

Andrén, A. 1993. Doors to other worlds: Scandinavian death rituals in Gotlandic perspectives, Journal of European Archaeology, 1, 33-56

Andrén, A. 2000. Re-reading embodied texts - an interpretation of runestones, Current Swedish Archaeology, 8, 7-32 
Arwill-Nordbladh, E. 2011. Förmåga och oförmåga. Om funktionsvariationer och kroppsliga möjligheter i vikingatidens myt- och bildvärld, in $\mathrm{M}$. Sjöberg (ed.), Bildligt talat. Kvinnligt, manligt i 3,2 miljoner år, 97-121, Göteborg/Stockholm: Makadam förlag

Back Danielsson, I.-M. 2007. Masking Moments. The Transition of Bodies and Beings in Late Iron Age Scandinavia, Stockholm: Stockholm University

Back Danielsson, I.-M. Forthcoming. Norsborgsparken, Stockholm: Stockholm University

Back Danielsson, I.-M., Fahlander, F. and Sjöstrand, Y. (eds). 2012. Imagery beyond representation, in I.-M. Back Danielsson, F. Fahlander and Y. Sjöberg (eds), 1-12, Encountering Imagery. Materialities, Perceptions, Relations, Stockholm: Stockholm University

Bender, B. 2002. Time and landscape, Current Anthropology, 43, 103-12

Bianchi, M. 2010. Runor som resurs. Vikingatida skriftkultur $i$ Uppland och Södermanland, Runrön 20. Uppsala: Uppsala University

Bindberg, L. V. R. 2006. Runstenar i kyrkomiljö, en länk mellan hednisk tradition och kristen tro? En studie av senvikingatida runstenar anknutna till kyrkor i Jönköpings län, BA thesis, Lund University

Brate, E. and Wessén, E. 1936. Södermanlands runinskrifter granskade och tolkade av Erik Brate och Elias Wessén, Sveriges Runinskrifter, Stockholm: Kungliga Vitterhets-Historie- och Antikvitets Akademien

Breisch, A. 1994. Law and Outlawry: Social Ties and Outcast in Early Medieval Iceland, Studia historica Upsaliensia, 174, Uppsala and Stockholm: Uppsala University and Almqvist and Wiksell International

Brendalsmo, J. and Røthe, G. 1992. Haugbrot eller de levendes forhold til de døde - en komparativ analyse, Meta, 1-2, 84-111

Cadman, L. 2009. Nonrepresentational Theory/Nonrepresentational Geographies, in R. Kitchin and N. Thrift (eds), International Encyclopaedia of Human Geography, 456-63, Amsterdam: Elsevier

Chapman, J. 1997. Places as time marks: the social construction of landscapes in east Hungary, in J. Chapman and P. Dolukhanov (eds), Landscapes in Flux, 137-62, Oxford: Oxbow Books

Conkey, M. W. and Gero, J. 1997. Programme to practice: gender and feminism in archaeology, Annual Review of Anthropology, 26, 411-37

Connerton, P. 1989. How Societies Remember, Cambridge: Cambridge University Press

Deleuze, G. 1986. Cinema I: The Movement-Image, translated by $\mathrm{H}$. Tomlinson and B. Habberjam, Minneapolis, MN: University of Minnesota Press

Douglas, M. 1966. Purity and Danger: an Analysis of the Concept of Pollution and Taboo, London: Routledge and Kegan Paul

Douglas, M. 1970. Natural Symbols: Explorations in Cosmology, New York: Vintage Books 
Edmonds, M. 1999. Ancestral Geographies in Neolithic Landscapes. Landscapes, Monuments and Memory, London: Routledge

Ekholm, G. 1950. Var restes runstenarna? Fornvännen,137-47

Engesveen, A. T. 2005. På vei mellom levende og døde. En analyse av forholdet mellom veier og graver $i$ Vestfold $i$ vikingtid, Hovudfagsoppgåve i nordisk arkeologi, Oslo: Oslo University

Eriksson, ̊. 1982. Fornstig och gammelväg: historiska strövtåg $i$ Stockholmstrakten, Stockholm: Nordstedts

Fenger, O. 1982. Ätt. Danmark, Kulturhistoriskt lexikon för nordisk medeltid från vikingatid till reformationstid

Friesen, O. von. 1913. Upplands Runstenar: en Allmänfattlig Öfversikt, Uppsala: Akad. Bo

Gansum, T. 1999. Mythos, logos, ritus. Symbolisme og gravskikk i lys av gudediktene i den eldre Edda, in B. Myhre, I. Fuglestvedt, T. Gansum and A. Opedal (eds), Et hus med mange rom. En venbok til Björn Myhre, 438-501, Stavanger: Arkeologisk museum i Stavanger

Gansum, T. 2004a. Role of the bones - from iron to steel, Norwegian Archaeological Review, 37(1), 41-57

Gansum, T. 2004b. Jernets fødsel og dødens stål. Rituell bruk av bein, in Å. Berggren, S. Arvidsson and A.-M. Hållans (eds), Minne och myt. Konsten att skapa det förflutna, 121-55, Vägar till Midgård 5, Lund: Nordic Academic Press

Gosden, C. 1994. Social Being and Time, Oxford: Blackwell

Gosden, C. 2005. What do objects want? Journal of Archaeological Method and Theory, 12, 193-211

Gosden, C. and Lock, G. 1998. Prehistoric histories, World Archaeology, 30(1), 2-12

Gräslund, A.-S. 1991. Runstenar - om ornamentik och datering, Tor, 23, $113-40$

Gräslund, A.-S. 1992. Runstenar - om ornamentik och datering II, Tor, 24, 177-201

Gräslund, A.-S. 2001. Ideologi och mentalitet: om religionsskiftet $i$ Skandinavien från en arkeologisk horisont, Uppsala: Uppsala University

Gustavson, H. 1995. Runorna under vikingatiden, in C. Orrling (ed.), Vikingatidens ABC, 216-20, Stockholm: SHM

Hafström, G. 1982. Ätt, Sverige, Kulturhistoriskt lexikon för nordisk medeltid från vikingatid till reformationstid

Halbwachs, M. 1993 [1950]. On Collective Memory, Chicago: University of Chicago Press

Hamre, L. 1982. Ätt, Norge, Kulturhistoriskt lexikon för nordisk medeltid från vikingatid till reformationstid

Haraway, D. 1996. Situated knowledges: the science question in feminism and the privilege of partial perspective, in H. Longino (ed.), Feminism and Science, 249-63, Oxford: Oxford University Press 
Harding, S. 1987. Feminism and Methodology, Bloomington, IN: Indiana University

Harding, S. 1993. Rethinking standpoint epistemology: what is 'strong objectivity'? in L. Alcoff and E. Potter (eds), Feminist Epistemologies, 49-82, New York: Routledge

Hellquist, E. 1980. Svensk etymologisk ordbok. Malmö: Gleerups förlag

Ingold, T. 1993. The temporality of the landscape, World Archaeology, 25, $152-74$

Ingold, T. 20oo. Stop, look and listen! Vision, hearing and human movement, in T. Ingold (ed.), The Perception of the Environment: Essays in Livelihood, Dwelling and Skill, 243-89, Routledge: London

Jacobsen, L. and Moltke, E. 1942. Danmarks Runeindskrifter. Text. København: Ejnar Munksgaards Forlag

Jansson, S. B. F. 1984. Runinskrifter $i$ Sverige. Uppsala: Almqvist and Wiksell Förlag AB

Jesch, J. 1998. Still standing in Ågersta: textuality and literacy in Late Viking Age rune-stone inscriptions, in K. Düwel (ed.), Runeninschriften als Quellen interdisziplinärer Forschung, 462-75, Berlin: Walter de Gruyter Jesch, J. 2005. Memorials in speech and writing, Hikuin, 32, 95-104.

Jesch, J. 2011. Runic inscriptions and the vocabulary of land, lordship, and social power in the late Viking Age, in S. M. Sindbæk and B. Poulsen (eds), Settlement and Lordship in Viking and Early Medieval Scandinavia, 31-44, Turnhout: Brepols

Johansen, B. 1997. Ormalur. Aspekter av tillvaro och landskap. Stockholm Studies in Archaeology, 14, Stockholm: Stockholm University

Jones, A. 2006. Animated images. images, agency and landscape in Kilmartin, Argyll, Journal of Material Culture, 11 (1/2), 211-26

Jones, A. 2007. Memory and Material Culture, Cambridge: Cambridge University Press

Jones, A. 2012. Prehistoric Materialities. Becoming Material in Prehistoric Britain and Ireland, Oxford: Oxford University Press

Joyce, R. 2003. Concrete memories. Fragments of the past in Classic Maya present (500-1000 AD), in R. M. Van Dyke and S. Alcock (eds), Archaeologies of Memory, 104-26, Oxford: Blackwell

Kulturhistoriskt lexikon för nordisk medeltid från vikingatid till reformationstid. København: Rosenkilde og Bagger, 1980-82.

Klos, L. 2009. Runensteine in Schweden. Studien zu Aufstellungsort und Funktion. Er-gänzungsbände zum Reallexikon der Germanishen Altertumskunde, 64, Berlin-New York: Walter de Gruyter

Lager, L. 2002. Den synliga tron. Runstenskors som en spegling av kristnandet i Sverige, OPIA 31, Uppsala: Uppsala University.

Lamm, J. P. 1995. Ätt, in C. Orrling (ed.), Vikingatidens ABC, 140, Stockholm: SHM.

Langer, S. 1984. Philosophy in a New Key: A Study in the Symbolism of Reason, Rite, and Art, Cambridge, MA: Harvard University Press 
Larsson, M. G. 1990. Runstenar och utlandsfärder: aspekter på det senvikingatida samhället med utgångspunkt i de fasta fornlämningarna, Stockholm: Almquist and Wiksell

Lindal, S. 1982. Ätt, Island, KLNM

Lindeberg, M. 2009. Järn i jorden: spadformiga ämnesjärn i Mellannorrland, Stockholm: Stockholm University

Lindqvist, S. 1941. Gotlands Bildsteine 1, Stockholm: Wahlström and Widstrand

Lindqvist, S. 1942. Gotlands Bildsteine 2, Stockholm: Wahlström and Widstrand

Longino, H. E. 1994. In search of feminist epistemology. The Monist, 77(4), $472-485$.

Lund, J. 2005. Thresholds and passages: the meanings of bridges and crossings in the Viking Age and Early Middle Ages. Viking and Medieval Scandinavia, 1, 109-35

Mauss 1992 [1934]. Techniques of the body, in J. Crary and S. Kwinter (eds), Incorporations, 455-77, New York: Zone

Merleau-Ponty, M. 1962. Phenomenology of Perception, London: Routledge

Middleton, D. and Edwards, D. (eds) 1997. Collective Remembering, London: Sage

Mitchell, T. 1996. What do pictures really want? October, 77, 71-82

Mitchell, T. 2005. What Do Pictures Want? The Lives and Loves of Images, Chicago: University of Chicago Press

Norr, S. and Sanmark, A. 2008. Tingsplatser, makt och landskap, in M. Olausson (ed.), Hem till Jarlabanke. Jord, makt och evigt liv i östra Mälardalen under järnålder och medeltid, 379-96, Lund: Historiska Media

Peterson, L. 1994. Svenskt Runordsregister, Runrön 2, second revised edition, Uppsala: Uppsala University

Price, N. 2010. Passing into poetry: Viking Age mortuary drama and the origins of Norse mythology, Medieval Archaeology, 54, 123-56

Samnordisk Runtextdatabas. http://www.nordiska.uu.se/forskn/samnord. htm

Sawyer, B. 2000. The Viking Age Rune-Stones. Custom and Commemoration in Early Medieval Scandinavia, Oxford: Oxford University Press

Sawyer, B. 2002. Runstenar och förmedeltida arvsförhållanden, in J. Agertz and L. Varenius (eds), Om runstenar i Jönköpings län, 55-79, Jönköping: Jönköpings läns museum

Snædal Brink, T. 1981. Jarlabankebrostenarna, in L. Thunmark-Nylén, J. P. Lamm, G. Tégner and A. Sandwall (eds), Vikingatidens ABC, 129-30, Stockholm: SHM

Stoklund, M. 2005. Tolkningen Baekke-, Laeborg- og Jelling-indskrifterne og meningen med at rejse runesten, Hikuin, 32, 37-48.

Tronner, K., Nord, A. and Gustavson, H. 2002. 'stenarna dessa, röda av runor-': undersökning av färgrester på bemålad sten från vikingatiden, 
in J. Agertz and L. Varenius (eds), Om runstenar i Jönköpings län, 197-210, Jönköping: Jönköpings läns museum

Van Dyke, R. M. 2011. Imagined pasts imagined. Memory and ideology in archaeology, in R. Bernbeck and R. H. McGuire (eds), Ideologies in Archaeology, 233-53, Tuscon: University of Arizona Press

Wiker, G. 2000. Gullbrakteatene - i dialog med naturkreftene. Ideologi og endring sett $i$ lys av de skandinavise brakteatnedleggelsene, Oslo: Oslo University

Williams, H. 2004. Death warmed up, Journal of Material Culture, 9(3), 263-91

Williams, H. 2006. Death and Memory in Early Medieval Britain, Cambridge: Cambridge University Press

Wylie, A. 2007. Doing archaeology as a feminist: introduction, Journal of Archaeological Method and Theory, 14, 209-16

Young, I. M. 1980. Throwing like a girl: a phenomenology of feminine body comportment, motility and spatiality, Human Studies, 3, 137-56

Zachrisson, T. 1998. Gård, gräns, gravfält. Sammanhang kring ädelmetalldepåer och runstenar från vikingatid och medeltid $i$ Uppland och Gästrikland, Stockholm: Stockholm University 